\title{
Evaluation of the cytotoxic and mutagenic potentials of ethanolic extract of Baccharis gaudichaudiana DC., (Asteraceae)
}

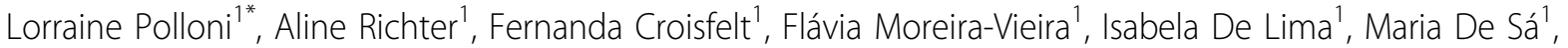 \\ Marcus Chaves', Sofia Antunes-Miranda', Thalita Silva', Vinicius Rodovalho', Mário Spanó ${ }^{1}$, Alexandre Rezende ${ }^{2}$
}

From 5th Congress of the Brazilian Biotechnology Society (SBBIOTEC)

Florianópolis, Brazil. 10-14 November 2013

\section{Background}

Evidenced by their traditional use and through scientific studies, natural products have been important participants in drug discovery, providing novel structures that can be used as potential drugs. Among the plants investigated to date, those of the Baccharis genus are important sources of natural medicinal products. Comprising more than 500 species distributed throughout the North and South American continents, this genus is commonly used in folk medicine as antipyretic agents, antirheumatic and to control hyperglycemia. B. gaudichaudiana, popularly known as "carquejeira-doce" is found in grasslands, Brazilian savannas, and less pronounced in tropical humid lowland. Many secondary metabolites have been characterized and isolated, such as flavonoids, diterpenes, tannins, saponins and essential oils.

\section{Methods}

In order to evaluate the cytotoxic and mutagenic potentials of the ethanolic extract of B. gaudichadiana, the Somatic Mutation and Recombination Test (SMART) in wing somatic cells of Drosophila melanogaster, was performed employing two genetic markers located on the left arm of chromosome 3: multiple wing hairs ( $m w h, 3-0.3)$ a homozygous-viable recessive mutation that produces multiple trichomes per cell instead of one trichome; and flare3 (flr3, 3-38.8) - a recessive mutation that produces flare-shaped wing hairs. Three D. melanogaster strains were used: 1$)$ multiple wing hairs: $y$; $m w h j$; 2) flare-3: flr3/ In (3LR)TM3, ri ppsep l(3)89Aa bx34ee BdS; and 3) ORR; flare-3: ORR; flr3/In(3LR)TM3, ri ppsep l(3)89Aa bx34ee

${ }^{1}$ Discente do Curso de Biotecnologia da Universidade Federal de Uberlândia, MG, Uberlândia, Brazil

Full list of author information is available at the end of the article
$B d S$. Two different crosses were carried out: Standard (ST) cross and High-Bioactivation (HB) cross. For the ST cross, virgin flare-3 females were mated with mwh males. For the HB cross, which is characterized by an augmented level of CYP 450, virgin ORR, flare-3 females were mated with mwh males. Third instar larvae obtained from both crosses were fed chronically ( $48 \mathrm{~h}$ ) with ethanolic extract of $B$. gaudichaudiana $(5,10,20,40$ or $80 \mathrm{mg} / \mathrm{mL})$. Ultrapure water (MilliQ) was used as negative control and urethane $(10 \mathrm{mM})$ as positive control.

\section{Results and conclusions}

The results from both crosses were rather similar. Concentrations between 5 to $40 \mathrm{mg} / \mathrm{mL}$ of the extract did not show cytotoxic activity. On the other hand, concentrations higher than $80 \mathrm{mg} / \mathrm{mL}$ significantly reduced the survival rates. The concentrations tested are not mutagenic in ST cross. However in HB cross, at higher concentration $(40 \mathrm{mg} / \mathrm{mL})$, the frequency of mutant spots was statistically increased. These results suggest that, under these experimental conditions, the ethanolic extract (at higher concentrations) might have compounds that, when metabolized by CYP450, can be mutagenic, and at high concentrations $(>80 \mathrm{mg} / \mathrm{mL}$ ), cytotoxic. However, further studies are needed to identify the constituents of this extract and confirm the efficacy and/or risks of its use, as well as to encourage the rational use of natural resources.

\section{Acknowledgements \\ FAPEMIG; CNPq; UFU; CAPES.}

\section{Authors' details}

${ }^{1}$ Discente do Curso de Biotecnologia da Universidade Federal de Uberlândia, MG, Uberlândia, Brazil. 'Laboratório de Mutagênese, Instituto de Genética e Bioquímica, Universidade Federal de Uberlândia, MG, Uberlândia, Brazil. 


\section{References}

1. Budel JM, Duarte MR, Santos CAM: Caracteres morfo-anatômicos de Baccharis gaudichaudiana DC., Asteraceae. Acta Farmacéutica Bonaerense 2003, 22(4):313-20, ISSN 0326-2383.

2. Budel JM, Duarte MR, Santos CAM: Parâmetros para análise de carqueja: comparação entre quatro espécies de Baccharis spp. (Asteraceae). Revista Brasileira de Farmacognosia 2004, 14(1):41-48, ISSN 0102-695X.

3. Graf $\mathrm{U}$, Würgler FE, Katz AJ, Frei $\mathrm{H}$, John H, Kale PG: Somatic mutation and recombination test in Drosophila melanogaster. Environmental Mutagenesis 1984, 6(2):153-88, doi: 6423380.

4. Rodrigues VEG, Carvalho DA: Levantamento etnobotânico de plantas medicinais no domínio do cerrado na região do alto do Rio Grande Minas Gerais. Ciências Agrotécnicas 2001, 25(1):102-123.

doi:10.1186/1753-6561-8-S4-P27

Cite this article as: Polloni et al:: Evaluation of the cytotoxic and mutagenic potentials of ethanolic extract of Baccharis gaudichaudiana DC., (Asteraceae). BMC Proceedings 2014 8(Suppl 4):P27.

\section{Submit your next manuscript to BioMed Central} and take full advantage of:

- Convenient online submission

- Thorough peer review

- No space constraints or color figure charges

- Immediate publication on acceptance

- Inclusion in PubMed, CAS, Scopus and Google Scholar

- Research which is freely available for redistribution

Submit your manuscript at www.biomedcentral.com/submit 